\title{
18
}

\section{Australian Thinking About Asia}

\author{
Michael Wesley
}

Like some of the other great scholars of the late twentieth century, it was war that introduced Bob $\mathrm{O}^{\prime}$ Neill to Asia. ${ }^{1}$ Already a wellcredentialed strategist and military historian, Bob was posted to Vietnam with the 5th Battalion, Royal Australian Regiment (5RAR), in May 1966, where from the start he began a diary which would become his second book, Vietnam Task. ${ }^{2}$ Tellingly, Bob titled the first chapter 'The Problem', and used it to inform the reader (initially his wife, Sally, to whom he posted instalments of his diary) about the terrain, politics, and military situation in South Vietnam. The chapter (like the rest of the book) shows a thorough-going strategist at work. 'The Problem' refers not self-indulgently to the plight of a young academic who has left his bride to enter a war zone, nor ideologically to the scourge of rampant Asian communism, but to a strategic challenge, to be thought about with the cold, dry logic of Liddell-Hart and Clausewitz, and addressed with the attitude that there can be a solution. Never one to think things half through, Bob didn't leave the Vietnam War behind when he shipped out in 1967, or when Vietnam Task was published in

\footnotetext{
1 Others who immediately come to mind include Clifford Geertz, Chalmers Johnson, and Stephan Haggard.

2 O'Neill, Robert J. (1968) Vietnam Task, Melbourne: Cassell.
} 
1968. In quick succession, Bob published an analysis of the Vietnam conflict $^{3}$ and a biography of General Giap, ${ }^{4}$ the strategist behind the forces against which Bob had been fighting.

In these early books, along with his monumental official history, Australia in the Korean War 1950-1953, ${ }^{5}$ Bob studied Vietnam and Korea closely, and thought about the contexts of these two conflicts deeply. His biography of General Giap, and his introductory chapter on the historical antecedents of the Korean War are testament to a scholar who read widely and thought profoundly about the local conditions and dynamics underpinning the two wars. His tenure as Head of ANU Strategic and Defence Studies Centre (SDSC) and then as Director of the International Institute of Strategic Studies (IISS) saw his attention return again and again to the strategic challenges of Asia. The conception of Asia that emerges from his writings is of a complicated and dynamic realm, less stable than any other region with the possible exception of the Middle East, and scantly covered by alliances, institutions, or other stabilising mechanisms. Asia is a region of intense competition within and between four layers of contention: the superpowers, the larger regional powers, the lesser regional powers, and various sub-national and transnational forces. ${ }^{6}$ It is a realm where some of the Cold War's strict divisions began to unravel, while others remained stubbornly militarised; a realm that delivers puzzling variations to Bob's enduring strategic interests, including nuclear strategy and insurgency. ${ }^{7}$

Bob's writings on Asia's strategic dynamics are a significant contribution to evolving Australian thinking on the security challenges it faced after the end of the Vietnam War. Although Australians have been pondering and writing about Asia since at least the mid-nineteenth century, ${ }^{8}$ the final quarter of the twentieth century became an

3 O'Neill, Robert J. (1968) The Indo China Tragedy, Melbourne: F. W. Cheshire.

4 O'Neill, Robert J. (1969) General Giap: Politician and Strategist, North Melbourne: Cassell.

5 O'Neill, Robert J. (1981) Australia in the Korean War 1950-53, Volume 1: Strategy and Diplomacy, Canberra: The Australian War Memorial and the Australian Government Publishing Service.

6 O'Neill, Robert J. (ed.) (1984) Security in East Asia, Adelphi Library 9, London: International Institute for Strategic Studies, p. vii.

7 O'Neill, Robert J. (ed.) (1987) East Asia, the West and International Security, London: Macmillan.

8 Walker, David (1999) Anxious Nation: Australia and the Rise of Asia, 1850-1939, St Lucia: University of Queensland Press. 
extremely fertile period of intellectual inquiry and policy development about Asia's evolving order and how Australia should relate to and, perhaps help shape, this order. Alongside the strategists were economists charting the beginnings of an era of explosive economic growth and its pervasive gravitational effects on the Australian economy. Political scientists delved into the sources of stability and instability within Australia's neighbours, charting the correlation of stable, if authoritarian, political settlements with sustained and remarkable equitable economic growth. Australian Government policy became closely entwined with these developments; initiatives such as the Pacific Economic Cooperation Council and Australia's initially isolated quest to find peace in Indochina saw academics and officials working closely together to address challenges and opportunities identified by both. The burst of policy innovation (the Defence of Australia) and institution building (Asia-Pacific Economic Cooperation (APEC), Association of Southeast Asian Nations (ASEAN) Regional Forum (ARF)) in the late 1980s and early 1990s was the culmination of Australian academics' and officials' long, entwined intellectual engagement with Asia.

And yet the founding of the ARF in 1994 can be seen as the conclusion of an era of Australian academic and official thinking about Asia. Many of the seeming verities that Australians had studied deeply in Asia seemed to have unravelled. For the strategists, with the end of the Cold War and the war in Indochina, there were new concerns: North Korea's nuclear program, China's assertiveness over the 1996 Taiwanese elections and the South China Sea, India's and Pakistan's breakout nuclear tests, and the fight to dislodge the Taliban and al Qaeda from Afghanistan and Pakistan. The economists were celebrating the arrival of the next rank of Asia's miracle - China, Thailand, and Indonesia - but, troublingly, the original miracle economy, Japan, had hit a wall from which it wouldn't recover. Then, in 1997, a financial crisis rippled across the region, rapidly reversing the miracle trade gains and casting doubt on the viability of state-directed approaches to economic development. The institutions created to great fanfare failed to live up to expectations; not only did they not galvanise in the face of security or financial crises, ${ }^{9}$ by the end of the century it was clear

9 Wesley, Michael (1999) 'The Asian Crisis and the Adequacy of Regional Institutions', Contemporary Southeast Asia 21(1), pp. 54-73; Acharya, Amitav (1999) 'Realism, Institutionalism and the Asian Economic Crisis', Contemporary Southeast Asia 21(1), pp. 1-29. 
that they had not been able to socialise a rising China to the region's norms and standards of behaviour. The political scientists saw their attention shift from authoritarian stability to democratic transition, instability, and increasing extremism. ${ }^{10}$

The quantum of Australian thinking about Asia did not abate after the mid-1990s; if anything, a greater range and diversity of voices joined the discussion. With the advent of the Howard Government in 1996, the close interaction between academics and officials on Australian policy towards the region frayed and at times became adversarial. Many of the themes and approaches to understanding Asia and Australia's relation to the region pioneered since the end of Vietnam War continued, but, perhaps reflecting the rate of change in the region itself, these were joined by new lines of inquiry and critique. In reviewing Australian thinking on Asia over the past two decades, I am going to separate Australian thinking about Asia from Australian thinking about how to relate to Asia. This is a somewhat artificial distinction, because there is an organic connection between a perspective on the region and a consequent attitude to how Australia should relate to the region. I try to rectify this distinction in the conclusion by identifying some of the continuities between understandings and prescriptions in the Australian conversation on Asia.

\section{What is Asia?}

'Asia' is a word heavily used in Australian political discourse, but its meanings are much less stable than those of other continents. Australian definitions of Asia have fluctuated according to the dynamics of wealth and power. In 1946, in mandating that its new national university in Canberra should devote one of four Research Schools to 'Pacific Studies', the Australian Government assumed all would know that this geographic designation was intended to include a large part of the Asian continent, on the verge of independence, and thus presenting a pressing imperative upon Australian government and society to understand the region. ${ }^{11}$ Soon after, under the terms of the 1948

10 Robison, Richard and Vedi R. Hadiz (2004) Reorganising Power in Indonesia: The Politics of Oligarchy in an Age of Markets, London: Routledge Curzon.

11 Australian National University Act 1946. Available at: www.comlaw.gov.au/Details/ C2004C02218. 
UKUSA signals intelligence agreement (between the United States, United Kingdom, Canada, Australia, and New Zealand), Australia was given responsibility for collecting and sharing intelligence on Southeast Asia and the South Pacific - thus drawing much tighter boundaries on Australia's Asian area of interest and expertise. ${ }^{12}$ Later, in 1951, Australia was a key player in the development of the Colombo Plan, which focused development assistance efforts on South and Southeast Asia. ${ }^{13}$ Also in 1951, Australia signed the ANZUS Treaty with the United States and New Zealand, which returned to a broader geographic scope of alliance obligations:

Each Party recognizes that an armed attack in the Pacific Area on any of the Parties would be dangerous to its own peace and safety and declares that it would act to meet the common danger in accordance with its constitutional processes. ${ }^{14}$

As we will see, the vagueness of the 'Pacific' definition of Asia so clear to those who had just lived through the Pacific War - would cause real misunderstandings and tensions in the Australia-US alliance after the turn of the twenty-first century.

Involvement in the Korean War, and the signing of a Commerce Agreement with Japan in 1957 and the subsequent boom in Australian trade with Northeast Asia broadened Australia's Asia interests beyond Southeast Asia and focused them from a diffuse Pacific area. ${ }^{15}$ At the same time, the communist victory in China, and Beijing's subsequent sponsorship of militant communist insurgencies throughout Southeast Asia, drew Australia's attention to Northeast and Southeast Asia as regions of primary security concern. ${ }^{16}$ This coincidence of Australia's economic and security interests in East Asia would endure past the end of the Vietnam War, the deep enmeshment of the Australian economy with Asia, and the end of the Cold War. The dismantling of the White Australia Policy in the early 1970s, followed by the large-scale

\footnotetext{
12 Ball, Desmond and Jeffery T. Richelson (1990) The Ties That Bind: Intelligence Cooperation Between the UKUSA Countries, Boston: Unwin Hyman.

13 Oakman, Daniel (2004) Facing Asia: A History of the Colombo Plan, Canberra: Pandanus Books.

14 Commonwealth of Australia (1951) ANZUS Treaty. Available at: australianpolitics.com/ topics/foreign-policy/anzus-treaty-text.

15 Tweedie, Sandra (1994) Trading Partners: Australia and Asia 1790-1993, Sydney: UNSW Press, pp. 154-6.

16 Millar, T. B. (1965) Australia's Defence, Melbourne: Melbourne University Press.
} 
acceptance of Vietnamese refugees under the Fraser Government, brought a demographic dimension to Australia's new enmeshment with East Asia. In the Australian vernacular, the term 'Asian' was used to refer to people of East Asian ethnicity, unlike in Britain, where 'Asians' were universally taken to be South Asians. So embedded had East Asia become in Australian definitions of Asia that Foreign Minister Gareth Evans felt comfortable enough to propose an 'East Asian Hemisphere' in 1995, complete with cartographic illustrations showing Australia as part of this hemisphere. ${ }^{17}$

Following the turn of the century, three events combined to disturb this comfortable truncation of Asia in the Australian mind. The first was the September 11 terrorist attacks on the United States, which saw Australian Prime Minister John Howard invoke the ANZUS Treaty for the first time in its history, and commit Australian forces to the invasions of Afghanistan in 2001 and Iraq in 2003. The second was increasing evidence that the post-1991 economic reforms in India were translating into rapid economic growth in the world's other billionplus people economy - which, in turn, were beginning to manifest in trade, investment and migration flows to Australia. Third was a rediscovery of geopolitical interest in the Indian Ocean, a part of the world that had not evinced much interest since the collapse of Soviet naval ambitions in the mid-1980s. ${ }^{18}$ It wasn't long before Australia's commitments in the Middle East and South Asia were causing tensions in its relations with some Southeast Asian countries, while forging new operational military partnerships with countries such as Japan in Northeast Asia. Meanwhile, concerns over China's assertiveness in the South and East China Seas gave rise to hopes that India would soon begin to play a credible balancing role to China's growing power, and a series of growing security relations between New Delhi and countries such as Japan and Vietnam. ${ }^{19}$ As a result, Australian commentators began to resurrect an older and largely forgotten term, the 'Indo-Pacific', as an explicit replacement of the term 'Asia Pacific'

17 Evans, Gareth (1995) 'Australia, ASEAN and the East Asian Hemisphere', Statement by the Australian Foreign Minister to the ASEAN PMC 7+1, Bandar Seri Bagawan, 2 August. Available at: www.gevans.org/speeches/old/1995/020895_australia_asean_eahemisphere.pdf.

18 Kaplan, Robert D. (2010) Monsoon: The Indian Ocean and the Battle for Supremacy in the Twenty-First Century, Melbourne: Black Inc Books.

19 Brewster, David (2012) India as an Asia Pacific Power, Abingdon: Routledge. 
to define the part of Asia of most relevance to Australia. ${ }^{20}$ The terms soon began to be picked up by policy-makers in Australia and the United States.

There is a case to be made that, despite this recent widening, the subdivision of Asia into segments that are of most interest to Australia makes little sense. The growing economic interdependence across Asia's subregions - in energy flows, investment, distributed manufacturing, and increasingly services - means that there is no one sub-region that is important on its own terms and independent of its relations with others. The growth in Asian powers' military capabilities and rivalries, and the recession of American strategic primacy means that drawing geopolitical boundaries around Asia's sub-regions makes little sense. The growth of institutions such as the Shanghai Cooperation Organisation, the One Belt-One Road and Eurasian Union initiatives, and the Asian Infrastructure Investment Banks shows that Asia's powers are not thinking in terms of Asia's subdivisions, but rather in terms of its possibilities and unities. Increasingly, I argue in my recent book, it will only make sense to think of Asia as a geographic whole - from the Pacific to the Mediterranean, from the Arctic to the Indian Ocean. ${ }^{21}$

Quite apart from the geographic definition of Asia, Australians have long discussed Asia as a cultural challenge to a Western society moored a long way from its cultural kin in Europe and North America. Primary among the newly independent Commonwealth's impulses towards the societies to its north west was a desire to assert the superiority of Australia's 'Anglo-Saxon' culture and institutions, and a desire to keep out the polluting influence of what were assumed to be 'lesser' Asian races. ${ }^{22}$ The first piece of legislation issued by the Commonwealth Parliament in 1901 was the Immigration Restriction Act, which established the White Australia Policy, which would endure for over 70 years. Yet, at the same time as these fearful, exclusionary impulses were dominant, there was a constant sub-theme of Australians

20 Wesley, Michael (2011) There Goes the Neighbourhood: Australia and the Rise of Asia, Sydney: NewSouth Books; Medcalf, Rory (2013) 'Indo-Pacific: What's in a Name?', in Michael Fullilove and Anthony Bubalo (eds), Reports From a Turbulent Decade, Melbourne: Viking.

21 Wesley, Michael (2015) Restless Continent: Wealth, Rivalry and Asia's New Geopolitics, Melbourne: Black Inc Books.

22 Reynolds, Henry and Marylin Lake (2008) Drawing the Global Colour Line: White Men's Countries and the Question of Racial Equality, Melbourne: Melbourne University Press. 
fascinated by the antiquity and sophistication of Asian cultures and religions. The study of Asian thought and society, and increasingly tourism to Asia became a significant current in Australian society from the late nineteenth century. ${ }^{23}$

With the end of the Second World War and the coming of independence to the countries of Asia, Australian writers began to question the compatibility of the White Australia Policy with the imperative of building close relations with the new states to our north. ${ }^{24}$ The growing assertiveness of post-colonial states in the United Nations over racial questions during the 1960s saw the Australian Government begin to quietly dismantle the White Australia Policy. And as security and economic trends drew Australia's attention ever more insistently towards Asia, there was a surge in Australian research and writing on the impact of cultural and values differences on international relations and foreign policy. ${ }^{25}$ The Australian debates and discussions at the time were affected by two external factors: the worldwide resurgence of regionalism at the end of the Cold War, and the surge of debate around the impact of culture on world politics following the publication of Samuel Huntington's essay, 'The Clash of Civilizations?'. ${ }^{26}$ Huntington explicitly drew Australia into his provocative argument, labelling it a 'torn country in reverse' whose 'current leaders are in effect proposing that it defect from the West, redefine itself as an Asian country and cultivate close ties with its neighbours' ${ }^{27}$ Huntington's intervention had the effect of further politicising Australia's policy of enmeshment with the Asian region, with opposition leader John Howard accusing

23 Walker, David (1999) Anxious Nation: Australia and the Rise of Asia, 1850-1939, St Lucia: University of Queensland Press; Strahan, Lachlan (1996) Australia's China: Changing Perceptions from the 1930s to the 1990s, Cambridge: Cambridge University Press; McFarlane, Jenny (2006) A Sacred Space: Theosophy and Alternative Modernism in Australia, 1890-1934, PhD Thesis, The Australian National University.

24 Levi, Walter (1947) American-Australian Relations, Minneapolis: Minnesota University Press; Borrie, W. D. (1950) 'Australian Population and its Relation to Asia', Australian Outlook 4(3), pp. 162-9; Crocker, Walter R. (1956) The Racial Factor in International Relations, Canberra: Australian National University Press.

25 Viviani, Nancy (1993) 'The Politics of Nationalism and Regionalism in Australia', Asian Journal of Political Science 1(2), pp. 39-56; Milner, Anthony and Mary Quilty (1995) Comparing Cultures, Melbourne: Oxford University Press; FitzGerald, Stephen (1997) Is Australia an Asian Country? Sydney: Allen \& Unwin.

26 Huntington, Samuel P. (1993) 'The Clash of Civilizations?' Foreign Affairs 72(3), pp. 22-49.

27 Ibid., p. 45 
the government of selling out Australia's identity, and Prime Minister Paul Keating vehemently rejecting Huntington's and Howard's characterisations. $^{28}$

The imperative of post-Cold War regionalism also added intensity to the debate within Australia. Being so dependent on the region for economic and security reasons, Canberra sensed the danger of being left on the outer if an exclusionary bloc were to form in East Asia. This was heightened by Malaysia's combative Prime Minister Mahathir, who championed Asian regionalism in explicitly cultural terms (while conveniently glossing over the differences among Asian societies by promoting the idea of common Asian values). Foreign Minister Gareth Evans argued that cultural differences were becoming less and less relevant in the age of globalisation, while his successor Alexander Downer argued that Australia's cultural differences with Asian societies mattered little given the wide cultural and values differences among Asian societies. In the end, Mahathir's vision of an exclusionary, Asianist regional grouping was rejected in favour of the open regionalism embodied by APEC, the ARF, and eventually the East Asia Summit. The intensity of discussions about Australia's cultural differences with East Asian societies were themselves superseded by a post-9/11 anxiety about asylum seekers from South and West Asia and a growing debate about how Australian society should relate to Muslim communities within and beyond its borders. ${ }^{29}$

A third theme in Australian thinking about Asia has been a repeated return to using Asia as a mirror in which Australian society appraises itself. Australian society's comfortable sense of superiority to the societies to its north began to be unsettled in the 1960s as the Japanese economy boomed, soon to be followed by the economies of South Korea, Taiwan, Hong Kong, and a procession of Asian tigers. The period of Asia's economic boom coincided with the end of Australia's own postwar long boom. After 1974, Australia's economy succumbed to over a decade of sluggish growth, high inflation and unemployment, and collapsing consumer and export demand, while a succession of Asian economies industrialised and grew at the fastest rates ever seen.

28 Keating, Paul (2000) Engagement: Australia Faces the Asia Pacific, Sydney: Pan Macmillan; Wesley, Michael (2007) The Howard Paradox: Australian Diplomacy in Asia 1996-2006, Sydney: ABC Books.

29 Burke, Anthony (2008) Fear of Security: Australia's Invasion Anxiety, Melbourne: Cambridge University Press. 
Australians could no longer look to Europe and America for solutions, because these regions were suffering as severe economic recessions as Australia. Inevitably, comparisons began to be made between a struggling Australian economy and the booming fortunes of its neighbours. ${ }^{30}$ These anxieties were only stoked by Asian leaders, such as Singapore's Lee Kwan Yew, who warned Australians that unless they changed they would become the 'poor white trash of Asia'. Treasurer Paul Keating seemed to echo Lee's warning when he famously said in 1986 that Australia risked becoming a 'banana republic' if it did not deregulate and diversify its economy.

Partly against the background of Australia's lagging performance compared to Asia's, a broad suite of liberalising economic reforms were undertaken in the 1980s and 1990s. ${ }^{31}$ By the mid-1990s, the Australian economy had entered a period of expansion and prosperity that was to survive three global and regional slowdowns, coming to be seen as a miracle economy. It was in this state of economic buoyancy that Australia watched the tiger economies to its north stumble first Japan's long recession, then the collapse of the Thai, Korean, Philippines, Malaysian, and Indonesian economies in the 1997-1998 Asian Financial Crisis. Suddenly the logic of comparison had flipped. Foreign Minister Downer couldn't resist providing some helpful inspiration to the struggling economies in Asia: 'we have through our own strong [economic] performance shown the region ... what commitment to openness and transparency in economic and political affairs can achieve'. ${ }^{32}$

Asia also provided a mirror to those Australians who worried about the country's alliance relationship with the United States. The alliance has been controversial for decades among those who worry that it makes Australia vulnerable as collateral damage in a possible nuclear exchange $^{33}$ or that Australia risks being dragged into American strategic mistakes. ${ }^{34}$ For many commentators of this view, the countries

\footnotetext{
30 Castles, Francis G. (1988) Australian Public Policy and Economic Vulnerability, Sydney: Allen \& Unwin; Drysdale, Peter (1988) International Economic Pluralism: Economic Policy in East Asia and the Pacific, Canberra: Australian National University Press.

31 Kelly, Paul (1992) The End of Certainty, Sydney: Allen \& Unwin.

32 Quoted in Wesley, Michael (2011) There Goes the Neighbourhood: Australia and the Rise of Asia, Sydney: NewSouth Books, p. 310.

33 Camilleri, Joseph A. (1987) ANZUS: Australia's Predicament in the Nuclear Age, Melbourne: Macmillan.

34 Wilkie, Andrew (2004) Axis of Deceit, Melbourne: Black Inc Agenda.
} 
of Asia that refused to align with either side of the Cold War divide, or those that did ally but in a low key, ambiguous way, provided a clear example of how a country in Australia's neighbourhood could maintain its security without compromising its foreign policy independence. ${ }^{35}$ In some iterations of this argument, Australia's close alignment with the United States was a major factor that prevented it from playing a genuine insider's role in Asia. ${ }^{36}$ On the other side of this debate were those who argued that rather than diminishing Australia's influence in Asia, the US alliance actually enhances it. ${ }^{37}$

The rise of China as Australia's most important economic partner emerged as a major complication in managing a bifurcation of Australia's economic and security interests. Like many regional countries, Australia has tightened its security relationship with the United States as it has been drawn ever more powerfully into China's economic orbit. The thickening economic relationship with China has repeatedly raised questions over whether, if China and the United States were to come to blows, Australia would support its ally or remain aloof in the interests of preserving its economic relationship with China. Here, the ambiguity of the ANZUS Treaty's wording has not helped. While some Australian leaders, such as Kevin Rudd, have been clear in their intention to side with Washington, others, such as Alexander Downer and Defence Minister David Johnston, have been much more equivocal. The changing structure of forces in the Pacific has led some scholars to argue that the balance of risks within the alliance has shifted, as the United States has moved from being at risk of entrapment to a risk of abandonment by its smaller ally. ${ }^{38}$

Another Asian mirror shed light on Australian values for many commentators. After promising democratic starts, many of Asia's countries lurched towards semi-authoritarian one-party rule in the decades after independence. ${ }^{39} \mathrm{At}$ times this led to bitter divisions among

35 Fraser, Malcolm, (2014) Dangerous Allies, Melbourne: Melbourne University Press.

36 Broinowski, Alison (2003) About Face: Asian Accounts of Australia, Melbourne: Scribe Publications.

37 Sheridan, Greg (2006) The Partnership: The Inside Story of the US-Australian Alliance Under Bush and Howard, Sydney: UNSW Press.

38 Green, Michael J., Peter J. Dean, Brendan Taylor and Zack Cooper (2015) The ANZUS Alliance in an Ascending Asia, Centre of Gravity Paper, Canberra: Strategic and Defence Studies Centre, The Australian National University.

39 Dressel, Bjeorn and Michael Wesley (2014) 'Asian States in Crisis', Strategic Analysis 38(4), pp. $452-3$. 
Australia's Asianist scholars, some of whom advocated continuing to study and engage with Australia's authoritarian neighbours, while others adopted a much more critical attitude to shortfalls in democracy, the rule of law, and human rights. ${ }^{40}$ Writers such as Pierre Ryckmans urged Australians not to be duped by superficial enthusiasm for countries such as the People's Republic of China, where vicious regimes were tearing societies apart. ${ }^{41}$ Ryckmans was particularly cutting about Australia jettisoning its moral compass in pursuit of material gains, arguing that admiration for Deng Xiaoping was the result of an eagerness for 'signing fat business deals with China'. ${ }^{42}$ Some Indonesianists were highly critical of Canberra's close relationship with the authoritarian, corrupt Suharto regime in Indonesia, directing particular criticism towards the Australian Defence Force's intimate embrace of the Indonesian Armed Forces, the cutting edge of repression and human rights abuses. Others argued that as Australia had become more integrated into Asian regional institutions, it had adopted a more Asian foreign policy stance in its increasing reluctance to criticise the internal practices of its co-members.

\section{Australia and Asia}

Of course, these different manifestations of Asia in the Australian imagination have often been related in some way to distinct opinions about how Australia should relate to the huge continent and archipelagos to its north. Perhaps the longest running theme on how Asia affects Australia centres around the several iterations of 'Asiapessimism' versus 'Asiaphoria'. Asiapessimists have come in several varieties. At the end of the Second World War, there were many Australians who were fearful of the prospect of a region of newly independent countries, believing that the new nations of the region would soon become prey to resurgent Japanese militarism or the march of Asian communism. ${ }^{43}$ The response was to pursue an alliance with the United States, push for a development assistance plan

40 See Kelly, David and Anthony Reid (eds) (1998) Asian Freedoms, Melbourne: Cambridge University Press.

41 Leys, Simon (1977) Chinese Shadows, New York: Viking Press.

42 Quoted in Strahan, Lachlan (1996) Australia's China: Changing Perceptions from the 1930s to the 1990s, Cambridge: Cambridge University Press, p. 302.

43 Fitzgerald, C. P. (1957) 'Australia in Asia', in Gordon Greenwood and Norman Harper (eds), Australia in World Affairs 1950-1955, Melbourne: F. W. Cheshire, p. 201. 
at Colombo to bolster resilience in new states, and adopt a forward defence strategy. ${ }^{44}$ More recent forms of Asiapessimism focus on the persistent or new causes of instability in Asia, from corruption and crime to environmental degradation, with several scholars pointing out the role of Australia's energy exports in Asia's mounting challenge to the global environment. ${ }^{45}$

On the other side were the Asiaphoric commentators who tended to see Asia's future as bright and therefore viewed Australia's future as clearly wedded to the booming countries to the north. Many saw the economic rise of Asia as a re-emergence of Asian societies to a place of global pre-eminence after the long night of colonialism, and celebrated the political and cultural decolonisation that was occurring as a consequence as Asian societies gained the confidence to stand up to Western dominance. ${ }^{46}$ Some could see the dawn of a new age in Asia's rise, a post-Western economic and security order to which Australia would have to adjust in order to secure its future. ${ }^{47}$ The logic was that Asia's rise was an opportunity for Australia, if only Australia could prove itself nimble and protean enough to make the most of this millennial activity. ${ }^{48}$ Others, particularly on the conservative side of politics, rejected the notion that Australia had to adjust to succeed in Asia; in Prime Minister John Howard's terms, Australia could make its way just by being ourselves. ${ }^{49}$

One interesting aspect of this debate is the extent to which the Asiapessimists are speaking a different language - that of strategy to that of the Asiaphorists - who speak the language of economics. This is particularly stark in relation to the rise of China and its likely impact on Australia. Strategists tend to see in China's rise the prospects of deepening rivalry with the United States and other Asian powers,

44 Lowe, David (1999) Menzies and the 'Great World Struggle': Australia's Cold War 1948-54, Sydney: UNSW Press; Edwards, Peter (2014) Australia and the Vietnam War, Sydney: NewSouth Books.

45 Dupont, Alan (1999) East Asia Imperilled, Melbourne: Cambridge University Press; Beeson, Mark (2011) 'Can Australia Save the World?: The Limits and Possibilities of Middle Power Diplomacy', Australian Journal of International Affairs 65 (5), pp. 563-77.

46 FitzGerald, Stephen (1997) Is Australia an Asian Country? Sydney: Allen \& Unwin, p. 42.

47 Garnaut, Ross (1989) Australia and the Northeast Asian Ascendancy, Canberra: Australian Government Public Service.

48 Australian Government (2012) Australia and the Asian Century, White Paper, Canberra: Commonwealth of Australia.

49 Wesley, Michael (2007) The Howard Paradox: Australian Diplomacy in Asia 1996-2006, Sydney: ABC Books. 
leading to the realistic prospect of war, including nuclear exchange. ${ }^{50}$ The prescription for Australia is, then, greater independence and activism, playing a role in coaxing the great powers towards some sort of mutual accommodation. The Asiaphorists see in China's rise a new phase of the global economy, in which Australia is particularly well placed to benefit from the remarkable complementarities between its own economy and the soon to be world's largest economy. The imperative of this school of thought is that Australia should get over its suspicions of China's different political and cultural system, and make the most of the demand and investment generated by its giant economy.

Another strand of thinking on Australia and its relation to Asia is the Engagement Project. Believers in the Engagement Project detected in the 1970s and 1980s that one consequence of the rise of Asia would be a challenge to the dominance of Western orders and norms as they applied to Australia's region. The end of the Vietnam War and the announcement of the Nixon Doctrine quickened Australia's search for an alternative defence doctrine to Forward Defence, and a decisive move towards the Defence of Australia Doctrine. ${ }^{51}$ Key government messaging around the new doctrine was that in the future, Australia would seek its security 'in Asia, not from Asia'. This new mantra coincided with the rise of the new regionalism around the world, as the Cold War came to an end. Eager to secure a founding membership of any Asian institutions that emerged, Australia became an active regionalist, promoting what were eventually to become APEC and the ARF, and campaigning against exclusivist cultural bloc proposals such as Dr Mahathir's East Asia Economic Caucus. Asian engagement became a defining foreign policy project for Australia and a significant issue in the country's domestic politics. The rhetoric of engagement was redolent with the implications of an apprenticeship: while other countries in the region were automatically assumed to be members, Australia needed to demonstrate its credentials and commitment to

50 White, Hugh (2012) The China Choice: Why America Should Share Power, Melbourne: Black Inc Books.

51 Dibb, Paul (1986) Review of Australia's Defence Capabilities, Canberra: Australian Government Public Service. Available at: www.defence.gov.au/se/publications/defreview/1986/ Review-of-Australias-Defence-Capabilities-1986.pdf. 
the Asian project - whatever that was. This attracted great attention among Australian scholars and policy-makers to the bounds and rules of the club that we were seeking to join. ${ }^{52}$

The engagement project became a significant issue in domestic politics. Whether Australia was a member of regional groupings (such as APEC and the ARF) or not (such as the Asia-Europe Meeting) became an issue of some controversy. Australian foreign policy actions, and even domestic political developments such as the rise of the xenophobic One Nation party, were appraised according to whether they advanced or hindered the engagement project. For some commentators, participation in the Iraq War or the failure to condemn racism in Australia meant that the 'dowry price just keeps rising'. ${ }^{53}$ On the other hand, Australian Foreign Minister Alexander Downer argued that Australia wasn't interested in joining all regional clubs - it was interested in 'practical regionalism', not 'emotional regionalism' ${ }^{54}$ The engagement project seemed to lose cache after Australia signed ASEAN's Treaty of Amity and Cooperation and joined the East Asia Summit in 2005. One scholar challenged Australia's foreign policy community to move on from the engagement era and find a new paradigm for dealing with the region as an acknowledged insider. ${ }^{55}$

\section{Conclusion}

Reviews of one nation's thinking about a particular subject are inevitably partial and reflective of the author's experiences and interests. I am aware also that the thinking about Asia I have set out seems very logically and clearly divided into different approaches and streams. The reality is that the Australian conversation about Asia has been ongoing and varied for close to two centuries. Themes merge and coincide; debates rage and die; and what appear to be

52 FitzGerald, Stephen (1997) Is Australia an Asian Country? Sydney: Allen \& Unwin; Ravenhill, John (2001) APEC and the Construction of Pacific Rim Regionalism, Cambridge: Cambridge University Press; Wesley, Michael (1997) 'The Politics of Exclusion: Australia, Turkey, and Definitions of Regionalism', The Pacific Review 10(4), pp. 523-55.

53 Broinowski, Alison (2003) About Face: Asian Accounts of Australia, Melbourne: Scribe Publications.

54 Wesley, Michael (2007) The Howard Paradox: Australian Diplomacy in Asia 1996-2006, Sydney: ABC Books, p. 155.

55 Carr, Andrew (2015) Winning the Peace: Australia's Campaign to Change the Asia Pacific, Melbourne: Melbourne University Press. 
new ideas turn out to have long historical antecedents. There have always been important connections between Australians' geographic definition of Asia and their thinking about the quest for membership and belonging. The irony is, of course, that in defining themselves into the region, the East Asian Hemispherists are at the same time defining out most of the societies that occupy that continent. Another intimate connection has been between currents of Asiaphoria and Asiapessimism, and discussions of whether the rise of Asia represents a challenge or alternative to Australia's Western identity. As observers have sometimes noted, Australian debates about the meaning of Asia's rise often say more about the people engaging in debate than the region they are debating. The same can be said about the various discussions that use Asia as a mirror to reflect on Australia's worth and values.

All of this was grist to Bob O'Neill's mill as he reflected on and wrote about the strategic dynamics of his time. When one reads Bob's writings, one can see the impact of Australia's rich debates about how it defines and relates to the culturally and developmentally different countries to its north. Even while Bob was in the UK, he kept abreast of the developments and debates in his native country, and his own intellectual projects returned regularly to the security dynamics of Asia. ${ }^{56}$ Bob's writings are and will remain part of the deep and dynamic conversation in Australia about Asia.

56 O'Neill, Robert J. (ed.) (1984) Security in East Asia, Adelphi Library 9, London: International Institute for Strategic Studies; O'Neill, Robert J. (1992) Security Challenges for Southeast Asia After the Cold War, Singapore: Institute of Southeast Asian Studies. 
This text is taken from War, Strategy and History: Essays in Honour of Professor Robert O'Neill, edited by Daniel Marston and Tamara Leahy, published 2016 by ANU Press, The Australian National University,

Canberra, Australia. 